\title{
DEVELOPING AN EFFECTIVE BEGINNING TEACHER SUPPORT SYSTEM FOR MODERN SCHOOLS
}

\section{DESARROLLO DE UN SISTEMA EFECTIVO DE APOYO PARA PROFESORES INICIALES PARA ESCUELAS MODERNAS}

\author{
Ilnur B. Garipov, Ramis R. Nasibullov, Ilnar F. Yarullin, Guzel R. \\ Nasibullova ${ }^{1}$
}

${ }^{1}$ Kazan Federal University, Kazan, Russia. e-mail: nasibullov_ramis@mail.ru Tel. +79276727238

Enviado: 27 de junio de 2019

Aceptado para publicar: 30 de julio de 2019

Publicado: 8 de agosto de 2019

\begin{abstract}
In today's context when the paradigm of education is shifting it is becoming apparent that there is a need for the new requirements for teacher education and novice teachers' competence. It is becoming particularly important for teachers to be mobile, flexible, able to adapt to social changes, prepared for constant development and innovative challenges, capable of being achievement-oriented and demanding towards one's own reflective, intellectual, ICT and communication competencies. This article provides an insight into novice teachers' professional adaptation that takes place during their induction. Moreover, we highlight the main psychological and pedagogical difficulties that novice teachers face. Along with that we present the main forms of support for novice teachers. The main goal of this study is to provide novice teachers with necessary support facilitate their further professional development, promote their self-realization and professional ambitiousness. Our literature review showed that this issue has been in the center of attention of various scientific schools. Within this article we develop the following aspects: creating conditions for successful novice teachers' adaptation, identifying novice teachers' professional problems and developing the ways to prevent these problems in their future work, facilitating novice teachers' engagement in all spheres of school life, supporting their development as creative and unique individuals, encouraging their professional thinking and preparedness for innovation and modernization. All in all our study demonstrated the importance of the issue and all aspects related to novice teachers' adaptation in today's schools.
\end{abstract}

Keywords: pedagogical support, professional adaptation, difficulties, novice teachers, contemporary school, mentoring, intrinsic motivation, encouragement.

En el contexto actual, cuando el paradigma de la educación está cambiando, se hace evidente que hay una necesidad de los nuevos requisitos para la formación docente y la competencia de los docentes novatos. Se está volviendo particularmente importante para los docentes ser móviles, flexibles, capaces de adaptarse a los cambios sociales, preparados para el desarrollo constante y los desafíos innovadores, capaces de orientarse hacia los logros y ser exigentes con las propias competencias reflexivas, intelectuales, de TIC y de comunicación. Este artículo proporciona una idea de la adaptación profesional de los maestros novatos que tiene lugar durante su inducción. Además, destacamos las principales dificultades psicológicas y pedagógicas que enfrentan los maestros novatos. Junto con eso, presentamos las principales formas de apoyo para maestros novatos. El objetivo principal de este estudio es proporcionar a los maestros novatos el apoyo necesario para facilitar su desarrollo profesional, promover su autorrealización y ambición profesional. Nuestra revisión de la literatura mostró que este tema ha estado en el centro de atención de varias escuelas científicas. Dentro de este artículo desarrollamos los siguientes aspectos: crear condiciones para la adaptación exitosa de los maestros novatos, identificar los problemas profesionales de los maestros novatos y desarrollar las formas de prevenir estos problemas en su trabajo futuro, facilitando la participación de los maestros novatos en todas las esferas de la vida escolar, apoyando su desarrollo como individuos creativos y únicos, fomentando su pensamiento profesional y preparación para la innovación y modernización. En general, nuestro estudio demostró la importancia del tema y todos los aspectos relacionados con la adaptación de los maestros novatos en las escuelas de hoy.

Palabras clave: apoyo pedagógico, adaptación profesional, dificultades, profesores novatos, escuela contemporánea, tutoría, motivación intrínseca, estímulo. 


\section{Introduction}

\section{The importance of the issue}

Creating necessary conditions for the professional adaptation of beginning teachers constitutes an important issue in the current system of education. It is becoming even more important today when the goal of developing a teacher candidate pool is being prioritized at the national level. Usually when new teachers join schools and face the first stage of adaptation, they experience stress and burnout, but for their organizations it is crucial to make sure that beginning teachers do not disrupt the educational process with its usual order of things. In view of this many educational organizations are concerned with creating necessary conditions for the continuing personal and professional development of beginning teachers and they are continuously looking into facilitating the process of teacher induction and adaptation. It is one of the priorities today to address this issue effectively. Professional adaptation lies in professional development and grasping the nature of teacher work. Every novice has to go through apprenticeship which is organized and reflected upon depending on previous experience.

\section{The importance of the issue}

The issue of teacher education and induction has long been studied by researchers and practitioners. Various aspects of novice teachers' work were discussed in the works of Kuzmina (1995), Zeichner \& Gore (1989), Bastian \& Marks (2017). However, this issue is far from being a priority within the current field of education and psychology despite being important in today's context. It is worth noting that the most impressive educational results are yielded through the team effort of beginning teachers and other school staff.

\section{Current state of the issue}

The issues related to the role of teachers in society along with the methodology and theory of their development have a long academic tradition and were developed in the works of Petty \& Hogben (1980), Power (1981), Yaakobi \& Sharan (1985).

The multifaceted nature of the teaching profession has been studied in the seminal works of (Chang, Fan \& Chen, 2017; Boylan, 2018; Nigris, 1988) highlighting how the personality of teachers as well as their creativity develop; focused on the issues of teacher education studied the patterns of teachers' professional development during their induction (Hogben \& Lawson, 1983). The works of Lushnikov (1991) deserve special attention for their analysis of beginning teachers' induction. The problems that beginning teachers experience in connection to professional adaptation can be divided into several groups:

- Problems stemming from incompetence in the fields of psychology, pedagogy and teaching methodology.

- Problems related to teachers' unpreparedness to be role models and moral leaders for their students;

- Problems stemming from communicative incompetence;

- Problems related to teachers' personal characteristics;

- Social problems.

\section{Study Methodology}

\section{The application of theoretical and empirical methods}

In order to achieve the set objectives and test the hypothesis we employed a number of research methods: philosophical, psychological and pedagogical literature review (academic articles on the issue by Russian and international authors); diagnostic methods (surveys, interviews, informal conversations, novice teachers' professional intentions and expectations analysis); observational methods (direct and indirect observations); document analysis; statistical data analysis; the interpretation of collected data and evaluation of results.

\section{Study basis}

The empirical part of the study took place at the schools affiliated with Kazan Federal University (comprehensive schools of general education \#15, \#103, comprehensive schools with advanced studying of certain subjects \#167, \#171, grammar schools \#3, \#10, \#13, \#15, \#20 as well as a number of rural schools in the Kaybickiy, Apastovskiy and Tetyusheskiy municipal districts in the Republic of Tatarstan).

\section{Research stages}

This study had three stages:

The first stage involved philosophical, pedagogical, and psychological literature review. Along with that we analyzed the work of novice teachers and the work of supervisors responsible for novice teachers' adaptation. Moreover, at this stage we developed a plan for our empirical work. At the second stage we tested our hypothesis and analyzed what conditions contribute to the effective professional adaptation of novice teachers. We also searched for and identified the nature of professional adaptation of teachers. Our study involved 127 beginning teachers, 16 head teachers, 34 deputy head teachers and 48 mentors. At the third stage we focused on studying the conditions that we perceived as contributing to successful adaptation. We also analyzed and 
discussed our findings and then systemized and generalized our results.

\section{Results}

The analysis of psychological and pedagogical literature, related to research topic, reveals that scholars have not yet agreed on a unified definition of adaptation, its types, content, and interlinkages. The notion of professional adaptation of teachers has received increased attention across a number of disciplines in recent years and is regarded as a separate stage of continuing professional and personal development. We consider professional adaptation as a process contributing to achieving a balance between a set of requirements for teachers and the implementation of these requirements in a particular educational establishment, presupposing professional socialization of personality, driven by a need for personal fulfilment and self-education. Professional self-education is seen as a nexus between education obtained at the university and subsequent enhancement of professional skills and psychological, pedagogical, methodological, and subject specific knowledge. Professional selfeducation also requires consolidation of pedagogical knowledge and experience by means of targeted and systematic independent work.

The study on the essence of professional adaptation of beginning teachers has necessitated identification of factors influencing this process. In this research, we were interested in a group of factors having substantial influence on professional adaptation of teachers at the beginning of their career. The results of this study reveal that key factors influencing professional adaptation include the composition of teaching staff, organization and content of work, motivation and attitudes towards teaching profession, education, the work of the department responsible for the development of teaching methods. On the basis of the results obtained from surveys, observations, and interviews with teachers, we identified four groups of beginning teachers, namely, a 'successful' group, a 'manipulative' group, a 'problematic' group, and a 'crisis' group. The distinction of groups was based on the following criteria: future and present attitudes towards the teaching profession, professional future plans, the level of satisfaction with organization and contents of work. Of these, professional future plans represent the most important factor in our view. The 'successful' group comprises beginning teachers with a strong interest in teaching profession and positive attitudes towards it. They also have a clear focus on teaching and plan to continue their professional career.

Individuals in the 'manipulative' group include beginning teachers whose choice of teaching profession was influenced by external factors, so that they cannot adequately evaluate their pedagogical abilities. These teachers are aware of the importance of teaching profession, although they do not see themselves as a part of school community. Representatives of this group slowly adapt to school settings and question whether they can realize their potential.

The 'problematic' group is a reserve group, as it consists of teachers who have doubts about their choice, or are indifferent to teaching profession. Their career plans are unstable, they do not participate in school decision-making, and their role is limited to teaching the subjects in which they qualified.

The 'crisis' group consists of beginning teachers who have negative attitudes towards teaching and wish to change their job. They explore alternative careers (software engineer, interpreter, manager, etc.), avoid contact with colleagues, parents, pupils, and therefore demonstrate low job performance.

The distinction between the groups has enabled us to establish the scope of work on the development of pedagogical excellence and personal characteristics of beginning teachers, as it would result in their successful professional adaptation.

The purpose of the educational experiment was to develop and implement pedagogical conditions, as they are inextricably linked and are based on a person-oriented approach which ensures that beginning teachers develop and expose their creative individuality.

In our opinion, social and psychological climate of an educational institution is one of the pedagogical conditions. It can be described as a combination of psychological factors that encourage or impede joint professional activities, and depend on relationships among teaching staff, as they develop a sense of belonging. Interpersonal relationships in the workplace define whether beginning teachers will face many inevitable difficulties alone or receive substantial support from colleagues.

A study on types of interpersonal relationships with colleagues and management, as well as types of support for beginning teachers has enabled us to distinguish three groups of teaching staff. We consider that the first group of teaching staff is characterized by creative activities, collaboration, the passion for teaching profession, mutual understanding. There are $24.7 \%$ of such groups, however, $17.6 \%$ of beginning teachers work in them. The second type of groups of teaching staff $(45.7 \%)$ is marked by stable relationships among group members. Successes and failures are inevitable in this group, however, assistance to novice teachers is provided when needed or in case of conflict. $54.3 \%$ of beginning teachers belong to this group. The third type of groups of teaching staff $(31.4 \%)$, where interpersonal 
relationships among group members are indifferent, includes $27.8 \%$ of novice teachers.

Considerable attention was paid to organization and content of work of novice teachers, their professional and psychological activities, the evaluation of their satisfaction with work, the identification of factors hindering adaptation process. On the basis of this analysis, individual induction programs for novice teachers were developed.

Schools, which participated in the educational experiment, provided healthy social climate for teachers that is characterized by creative environment and mutual support. The correlation between the types of groups of teaching staff has changed by 2018 . The number of the first and the second type of groups of teaching staff has increased by $7.8 \%$ and $9.4 \%$ respectively. Consequently, the number of the third type of groups has diminished.

At the final stage of the experiment $71.4 \%$ of beginning teachers wished to continue working in their groups $(41.7 \%$ of novice teachers expressed their desire to remain in the same group three years ago), which proves that our work aimed at improving social climate at schools contributed to better professional adaptation of beginning teachers.

Our research, based on the educational experiment, revealed that a significant number of beginning teachers in Russia (78.4\%) need mentors. We identified a strong correlation between successful professional adaptation of novice teachers and their relationships with mentors.

The analysis of the results obtained in this research implies that our experiment was successful. There is an increasing trend in the number of beginning teachers who receive substantial support in all aspects of their career development.

We organized workshops for novice teachers to introduce them to innovative technologies, help them master skills in IT and its application in teaching, make them familiar with software and ways of obtaining and processing information.

Beginning teachers were provided with the necessary conditions for personal fulfilment and creative work in the 'successful' group. The major attention was paid to the cultivation of positive attitudes towards teaching profession and personal enrichment while working with members of the 'manipulative' group. Psychological background is important in the work with representatives of 'crisis' and 'problematic' group, as they need to overcome negative attitudes concerning teaching profession. It is crucial to provide them with competent mentors and help them overcome difficulties (Razavi et al, 2015; VargasHernández, 2016).

Overall, there have been positive changes in the composition of groups of beginning teachers.

\section{Discussion}

Beginning teachers' first years of work play a significant role in their professional and personal life. Personal development and self-evaluation determine success in teaching profession. The ways towards self-improvement and selfidentification may vary from one person to another. The work with children and relationships among teaching staff create an environment for the development of teachers' personality.

Practice shows that schools with a significant number of beginning teachers adjust quickly to new technologies and have a higher teaching quality and a higher status (Sinclair \& Aho, 2018). The present research does not fully cover all issues related to professional adaptation of beginning teachers. The further studies would cover self-actualization technologies, personal characteristics of beginning teachers, characteristics of teaching staff at different schools (selective schools, schools with a specific subject specialization) and their influence on the adaptation of beginning teachers.

\section{Conclusion}

It is theoretically justified that professional adaptation of beginning teachers is a process contributing to achieving a balance between a set of requirements for teachers and the implementation of these requirements in a particular educational establishment, presupposing professional socialization of personality, driven by a need for personal fulfilment and self-education.

It is defined that professional socialization is an integral and essential part of professional adaptation, as it occurs in a 'social space' and is seen as a process of integration of individuals into professional work environment. During this process, individuals also embrace standards and values developed by community of professionals, gain experience, and apply knowledge and skills in practice. The behavioral pattern, that teachers choose during their integration into professional work environment, is seen as the optimal behavioral solution (Kheirabadi \& Mirzaei; 2019; Eslami \& Ahmadi; 2019; Jabbari et al, 2019).

In conclusion, it is crucial to highlight prerequisites for successful adaptation of beginning teachers which are as follows: the development of mentoring tools; the provision of professional development for beginning teachers through cooperation and collaboration with other teachers; the implementation of the professional development program for beginning teachers contributing to their success in the first years of work; the encouragement of beginning teachers to participate in competitions providing rewards for 
results; the promotion of self-education and career development through the creation of conditions for improving beginning teachers' financial status; the promotion of access to higher education (Master's and $\mathrm{PhD}$ programs) for beginning teachers, as it develops expertise of teachers and improves the quality of teaching.

\section{Acknowledgments}

The research is performed according to the Russian Government Program of Competitive Growth of Kazan Federal University.

\section{References}

Bastian, K.C. \& Marks, J.T. (2017). Connecting Teacher Preparation to Teacher Induction: Outcomes for Beginning Teachers in a University-Based Support Program in Low-Performing Schools. American Educational Research Journal, 54(2), 360-394.

Boylan, M. (2018). Enabling adaptive system leadership: Teachers leading professional development. Educational Management Administration and Leadership, 46(1), 86-106.

Chang, W.C., Fan, C.W. \& Chen, C.H. (2017). Difficulties Facing the Accountability Leadership of Junior High School Principals and the Strategies They Employ: A Qualitative Approach. Journal of research in education sciences, 62(3), 57-93.

Eslami R, Ahmadi S. Investigating the Role of Educational Media on Secondary School Students' Learning Process Improvement in Jahrom City. Journal of Humanities Insights. 2019;3(01):13-6.

Hogben, D. \& Lawson, M. (1983). Attitudes of secondary school teacher trainees and their practice teaching supervisors. Journal of Education for Teaching, 9(3), 249-263.

Jabbari E, Charbaghi Z, Dana A. Investigating the Effects of Educational and Motivational Education at Different Levels on the Performance and Application of dart throwing. Journal of Humanities Insights. 2019;3(02):37-44.

Kheirabadi MA, Mirzaei Z. Descriptive valuation pattern in education and training system: a mixed study. Journal of Humanities Insights. 2019;3(01):7-12.

Kuzmina, N. (1995). Tyorcheskij potencial specialista. Akmeologicheskie problemy razvitija. [Creativity of professionals. Acmeological aspects of development]. Humanization of education-Russia, 1, 63-66.

Lushnikov, I. (1991). Professional'naja adaptacija vypusknikov pedinstituta
[Professional adaptation of graduates of pedagogical institutions]. Moscow: Prosveschenie. 340

Nigris, E. (1988). Stereotypical images of schooling: Teacher socialization and teacher education. Teacher Education Quarterly, 15(2), 4-19.
Petty, M.F., \& Hogben, D. (1980). Explorations of semantic space with beginning teachers: A study of socialization into teaching. British Journal of Teacher Education, 6(1), 51-61.

Power, P.G. (1981). Aspects of the transition from education student to beginning teacher. Australian Journal of Education, 25(3), 288296.

Razavi, S. M., Nasirian, M., \& Afkhami, I. (2015). The effectiveness sleep hygiene training on the job performance of employees Shift or rotating shifts parvadeh tabas coal companies in. UCT Journal of Management and Accounting Studies, 3(1), 5-7.

Sinclair, J. \& Aho, A. (2018). Experts on super innovators: understanding staff adoption of learning management systems. Higher Education Research \& Development, 37(1), 158-172.

Vargas-Hernández, J. G. (2016). THE QUESTION OF CHANGING THE CONCEPT, ROLE AND FUNCTIONS OF STATE. Humanities \& Social Sciences Reviews, 4(1), 08-19. https://doi.org/10.18510/hssr.2016.412

Yaakobi, D. \& Sharan, S. (1985). Teacher beliefs and practices: The discipline carries the message. Journal of Education for Teaching, I1(2), 187-199.

Zeichner, K.M., Gore, J.M. (1992). Teacher Socialization. New York, Macmillan, Journal of Education for Teaching, 18(31), 239-245. 